\title{
Corrigendum: Oligodendrocyte,
} Astrocyte and Microglia Crosstalk in Myelin Development, Damage, and Repair

\author{
Helena S. Domingues ${ }^{1,2 \dagger}$, Camila C. Portugal ${ }^{1,2 \dagger}$, Renato Socodato ${ }^{1,2 \dagger}$ and \\ João B. Relvas ${ }^{1,2 *}$ \\ ${ }^{1}$ Glial Cell Biology Group, Instituto de Biologia Molecular e Celular, Universidade do Porto, Porto, Portugal, ${ }^{2}$ Glial Cell Biology \\ Group, Instituto de Investigação e Inovação em Saúde, Universidade do Porto, Porto, Portugal
}

Keywords: oligodendrocyte, astrocyte, microglia, multiple sclerosis (MS), experimental autoimmune encephalomyelitis (EAE), myelination, demyelination, remyelination

\section{A corrigendum on}

Oligodendrocyte, Astrocyte, and Microglia Crosstalk in Myelin Development, Damage, and Repair

by Domingues, H. S., Portugal, C. C., Socodato, R., and Relvas, J. B. (2016). Front. Cell Dev. Biol. 4:71. doi: 10.3389/fcell.2016.00071

\section{OPEN ACCESS}

Edited and reviewed by:

Adelaide Fernandes,

University of Lisbon, Portugal

*Correspondence:

João B. Relvas

jrelvas@ibmc.up.pt

${ }^{\dagger}$ These authors have contributed equally to this work.

Specialty section:

This article was submitted to Molecular Medicine,

a section of the journa Frontiers in Cell and Developmental

Biology

Received: 13 July 2016 Accepted: 15 July 2016

Published: 19 July 2016

Citation:

Domingues HS, Portugal CC, Socodato $R$ and Relvas JB (2016) Corrigendum: Oligodendrocyte, Astrocyte and Microglia Crosstalk in Myelin Development, Damage, and Repair. Front. Cell Dev. Biol. 4:79.

doi: 10.3389/fcell.2016.00079
Reason for Corrigendum:

In the original Review article, we neglected to thank some of our sponsors. The correct funding statement is shown below. The authors apologize for this oversight. This error does not change the scientific conclusions of the article in any way.

Moreover, the Editorial Office and the handling Editor, Adelaide Fernandes, would like to state that while she published with Helena Sofia Domingues and João Bettencourt Relvas in 2014 and 2015, the review of the article was handled objectively.

\section{FUNDING}

HD, CP, and RS are supported with fellowships funded by Fundação para a Ciência e Tecnologia (FCT) (references SFRH/BPD/90268/2012 to HD, SFRH/BPD/91962/2012 to CP and SFRH/BPD/91833/2012 to RS). This article was funded by the project Norte-01-0145-FEDER000008000008-Porto Neurosciences and Neurologic Disease Research Initiative at I3S, supported by Norte Portugal Regional Operational Programme (NORTE 2020), under the PORTUGAL 2020 Partnership Agreement, through the European Regional Development Fund (ERDF).

Conflict of Interest Statement: The handling Editor has declared a past co-authorship with the authors HD and JR and states that the process nevertheless met the standards of a fair and objective review.

The other authors declare that the research was conducted in the absence of any commercial or financial relationships that could be construed as a potential conflict of interest.

Copyright (c) 2016 Domingues, Portugal, Socodato and Relvas. This is an open-access article distributed under the terms of the Creative Commons Attribution License (CC BY). The use, distribution or reproduction in other forums is permitted, provided the original author(s) or licensor are credited and that the original publication in this journal is cited, in accordance with accepted academic practice. No use, distribution or reproduction is permitted which does not comply with these terms. 